\title{
Joseph Ratzinger y el binomio "Fe y Racionalidad". Una relación necesaria para el cristianismo antiguo y presente
}

\author{
Ricardo Marcelino Rivas García \\ UNIVERSIDAD INTERCONTINENTAL \\ UNIVERSIDAD PONTIFICIA DE MÉXICO \\ rrivas@uic.edu.mx
}

\section{INTRODUCCIÓN}

El contexto cultural e intelectual en el que nos encontramos, en el que predomina la desconfianza en el logos, en la razón, ha pasado factura al cristianismo desde hace por lo menos dos siglos. Este "movimiento religioso", que no solo influyó sino que marcó muchos derroteros de la cultura occidental, se ha identificado con la verdad revelada (el Logos creador) y se ha considerado a sí mismo como compatible con la racionalidad "natural" humana (el logos humano). Además, siempre ha afirmado contar con una base racional o filosófica como precondición de la legitimidad y universalidad de su mensaje salvífico y de la teología desarrollada alrededor del mismo.

Es de todos sabido que la racionalidad se exacerbó en la Modernidad y de hecho los pensadores de ese periodo histórico se apropiaron y secularizaron al logos, para interpretar desde él el decurso de los acontecimientos humanos hacia una promesa de emancipación intrahistórica. En la primera parte de este ensayo mostraremos el horizonte en el que parece avizorarse el fracaso de la razón moderna. En el siguiente apartado revisaremos cómo el cristianismo se ha concebido a sí mismo como una religión ilustrada, cuya fe ha echado mano de la racionalidad crítica -que en los primeros siglos de su aparición dicha racionalidad se identificaba con la filosofía griega-. En el tercer apartado analizaremos la necesidad que tiene la religión cristiana, o cualquier propuesta religiosa, de mantenerse adscrita a la racionalidad si es que dicha creencia quiere presentarse como "creíble", como "razonablemente aceptable", en 
un contexto en el que proliferan las creencias banales, las supersticiones, al tiempo que aparece y renace una multiplicidad de mitos. La tesis del presente ensayo se resume en lo siguiente: el cristianismo debería reivindicar la racionalidad como un elemento inherente a la fe religiosa tal y como sucedió desde sus orígenes y en esa medida valorar su necesidad para el tiempo presente y futuro ${ }^{1}$.

\section{1. ¿EL "OCASO de la RAZÓN Y de la FILOSOFÍA"?}

Nos encontramos en un clima cultural desfavorable para el pensamiento en general y para la filosofía y la metafísica en particular. Este clima bien puede definirse como escepticismo epocal: paradójicamente, la época moderna significó la expansión del potencial de la razón y al mismo tiempo la definición de sus límites, acotando estos al margen de lo intramundano. Esto último se manifestó en el siglo XX, por un lado con la soberbia de una razón autosuficiente capaz de ejercer dominio sobre lo intramundano a través de la tecnociencia, pero por el otro, con una desconfianza generalizada en las posibilidades de alcanzar un conocimiento cierto de la estructura íntima de la realidad, del saber, de la verdad; menos aún del sentido de la vida y de la esencia del hombre y su destino trascendente. Lo anterior se puede ilustrar mejor desde la epistemología contemporánea, en la cual se ha identificado como rasgo determinante del carácter científico de cualquier propuesta teórica, no su verdad, no su capacidad de formular leyes, no sus aportaciones concluyentes, sino su valor tentativo, aproximativo, probable, falible [Popper] y hasta "incierto" o "indeterminado" [Heisenberg], lo cual garantiza su indefinido desarrollo.

Este escepticismo generalizado sobre todas aquellas cuestiones de ultimidad ha permeado las diferentes esferas de la cultura y ha estimulado un pesimismo no heroico, no trágico, descomprometido -a diferencia del pesimismo trágico pero solidario ante el absurdo de la existencia, tal como sucedió en la filosofía dominante en la primera mitad del siglo pasado-. La actual es una época de evasión, distracción, superficialidad, desencanto, apatía, indiferencia y pasividad. Tal entorno ha generado una actitud perpleja que alimenta la trivialización de las dimensiones profundas de la vida y las somete al criterio de funcionalidad. Hemos sido testigos en los últimos decenios de un cansancio cultural que des-

Cfr. J. Habermas, "Apostillas sobre una sociedad post-secular" en Revista colombiana de sociología, N³1, Bogotá, Colombia 2008, 169-183. 
motiva cualquier posibilidad de interrogarse por la realidad y, paradójicamente, motiva la búsqueda de la satisfacción inmediata del tener, acaparar, poseer y dominar.

Entre ciertos filósofos contemporáneos provenientes de diversas tradiciones y marcos teóricos -varios de procedencia nietzscheana-, entre los que podemos señalar a Heidegger, Gadamer, Adorno, Derrida, Foucault, Lyotard, Rorty, Vattimo y muchos otros, existe la premisa común según la cual el llamado "proyecto de la Modernidad" es responsable de tal estado cultural actual. También se asume que este proyecto está cimentado sobre una metafísica de la identidad; una metafísica que se ha empecinado en uniformizar la pluralidad y la heterogeneidad del ser, y esclerotizar en la "presencia" y en la "inmutabilidad" tanto el azar como el devenir que azota lo real. Según estos filósofos, tal obsesión por la unidad y la permanencia sería la causante de la decadencia cultural. No vamos a entrar en detalles sobre la metafísica de la identidad y sobre su agotamiento $^{2}$. Sin embargo, es notoria la decadencia que ha tenido el pensamiento filosófico en los últimos decenios.

Puede haber una relación directa entre la crisis de la cultura contemporánea y lo que Heidegger llamó el "olvido del ser", en cuanto que dicha crisis ha revelado el agotamiento de las pretensiones de totalidad y necesidad de la metafísica ${ }^{3}$. Tal olvido obligó a declarar "el fin de la metafísica", no porque esta haya dado cumplimiento a sus aspiraciones y metas, sino por la imposibilidad de tal cumplimiento. La Modernidad y su metafísica presupuesta han fracasado, al grado de que cualquier diagnóstico es improbable, como nos dice el propio Heidegger:

La decadencia espiritual de la tierra está tan avanzada que los pueblos amenazan con perder la última fuerza espiritual que puede hacer posible percibir la decadencia (mentada en relación con el destino del ser) y calibrarla como tal. Esta sencilla constatación nada tiene que ver con el pesimismo cultural, ni tampoco con el optimismo, por supuesto: porque la desertización del mundo, la huida de los dioses, la destrucción

2 Cfr. R. Rivas, “¿Superación de la metafísica? Una introducción problemática al 'pensamiento posmetafísico' de Habermas y Apel”. Efemérides Mexicana, vol. 28, n 83 mayo-agosto 2010, 296-335.

3 Cfr. M. Heidegger, Superación de la metafísica, en Heidegger, Conferencias y articulos, Serba, Barcelona, 1994. [ed. orig. 1936-1946], \$ XXVI; Heidegger, M. 1998, Ser y tiempo, F.C.E., México [ed. orig. 1927], 32-33. 
de la tierra, la masificación de los hombres, la sospecha llena de odio a que es sometido todo lo creador y libre han alcanzado ya tales dimensiones en la tierra entera, que categorías tan infantiles como pesimismo y optimismo hace mucho que no resultan ya sino risibles ${ }^{4}$.

En ese marco, puede entenderse que la decadencia intelectual nos obligue a dar el paso hacia la superación de la Modernidad y su metafísica, para superar a su vez tal crisis moral y cultural de nuestro tiempo5. Sin embargo, del hecho de que la Modernidad haya fracasado no significa que el pensamiento filosófico deba dejar paso al pensar poético, metafórico y lúdico. La racionalidad propia del pensamiento filosófico nació como instancia crítica y desmitificadora, y a pesar de las vicisitudes por las que atravesó la filosofía a lo largo de todo el siglo pasado, no podemos renunciar a esta tarea. ¿Qué queda en lo que se refiere a la religión?, ¿¿deberíamos retornar al pensamiento mágico y mítico?

El cristianismo primitivo recogió de la filosofía griega esa fundamental vocación desmitificadora ${ }^{6}$. Varios autores afirman el talante secularizador del cristianismo y un factor de ello es la apropiación de la racionalidad filosófica por parte de este movimiento religioso característico de Occidente ${ }^{7}$. Pero ¿por qué la racionalidad y el cristianismo -que se concibió a sí mismo desde sus orígenes como una religión ad hoc con la razón- se consideran contradictorios y hasta excluyentes en nuestra cultura moderna y contemporánea? ¿Qué cambió en la racionalidad, qué cambió en el cristianismo para que esto se diera de tal manera?

El modo contemporáneo en que se ha tratado de armonizar (o mejor dicho, distanciar) la religión cristiana y la racionalidad en el horizonte

4 M. Heidegger, Introducción a la metafísica, Gedisa, Barcelona [curso de 1935, publicado hasta 1987] 1988, 43.

5 Cfr. R. Rivas, Ensayos críticos sobre la posmodernidad. La crisis del sentido de la vida y la historia, Universidad Intercontinental, México 2013.

6 Esta es la tesis que nos proponemos desarrollar en el presente trabajo, para reflexionar, al mismo tiempo, sobre la necesidad de la racionalidad para el cristianismo hoy más que nunca.

7 Cfr. M. Weber, La ética protestante y el espiritu del capitalismo, FCE, México [ed. orig. 1904-1905] 2003; S. Bruce, "Secularization", en R. Segal (comp.), The Blackwell Companion to the Study of Religion, Malden, Blackwell 2006; M. Borghesi, Secularización y nihilismo. Cristianismo y cultura contemporánea, Encuentro, Madrid 2007; CH. TaYlor, A Secular Age, Harvard University Press, Cambridge 2007. 
cultural no es nuevo, puesto que encuentra precedentes en la Antigüedad. Porfirio, filósofo neoplatónico del s. II d. C., formulaba una idea fundamental: "la verdad está oculta" bre acerca de la verdad sobre Dios, tan solo opiniones. ¿Quiere decir que la crisis de la racionalidad moderna impacta en el carácter racional de la fe cristiana y por ello la única manera de relacionar a esta con la racionalidad es levantando una muralla, colocando al hombre y a la cultura de nuestro tiempo en un "agnosticismo" o un "escepticismo metódico"? Este no ha sido el parecer del cristianismo, ni desde la época de Porfirio ni actualmente. Vamos a analizar a continuación la relación constituyente que ha tenido la fe cristiana desde sus orígenes con la racionalidad, especialmente el tipo de racionalidad desarrollada en el pensamiento filosófico.

\section{2. ¿LA "RACiONALIDAD” DEL CRISTIANiSMo?}

Comencemos este apartado remitiéndonos a dos citas clave, una tomada del libro de la Sabiduría y la otra de la Carta de San Pablo a los Romanos, mismas que orientarán nuestro análisis:

Sí, vanos por naturaleza todos los hombres en quienes había ignorancia de Dios y no fueron capaces de conocer por las cosas buenas que se ven a Aquel que es, ni atendiendo a las obras, reconocieron al Artífice; sino que al fuego, al viento al aire ligero, a la bóveda estrellada, al agua impetuosa o a las lumbreras del cielo los consideraron como dioses, señores del mundo. Que si, cautivados por su belleza, los tomaron por dioses, sepan cuánto les aventaja el Señor de estos, pues fue el Autor mismo de la belleza quien los creó. Y si fue su poder y eficiencia lo que les dejó sobrecogidos, deduzcan de ahí cuánto más poderoso es Aquel que los hizo; pues de la grandeza y hermosura de las criaturas se llega, por analogía, a contemplar a su Autor. Con todo, no merecen estos tan grave reprensión, pues tal vez caminan desorientados buscando a Dios y queriéndole hallar. Como viven entre sus obras, se esfuerzan por conocerlas, y se dejan seducir por lo que ven. ¡Tan bellas se presentan a los ojos! Pero, por otra parte, tampoco son estos excusables; pues si llegaron a adquirir tanta ciencia que les capacitó para indagar el mundo, ¿`cómo no llegaron primero a descubrir a su Señor??.

\footnotetext{
8 Latet omne verum.

9 Sabiduría 13, 1-9.
} 
En efecto, la cólera de Dios se revela desde el cielo contra toda impiedad e injusticia de los hombres que aprisionan la verdad en la injusticia; pues lo que de Dios se puede conocer, está en ellos manifiesto: Dios se lo manifestó. Porque lo invisible de Dios, desde la creación del mundo, se deja ver a la inteligencia a través de sus obras: su poder eterno y su divinidad, de forma que son inexcusables; porque, habiendo conocido a Dios, no le glorificaron como a Dios ni le dieron gracias, antes bien se ofuscaron en sus razonamientos y su insensato corazón se entenebreció: jactándose de sabios se volvieron estúpidos, y cambiaron la gloria del Dios incorruptible por una representación en forma de hombre corruptible, de aves, de cuadrúpedos, de reptiles ${ }^{10}$.

Estas dos citas bíblicas nos ilustran acerca de la confianza que la tradición judeocristiana ha tenido en la razón humana, en el conocimiento natural del mundo, como vía mediata para conocer a Dios. Fundamental lo que subraya el libro de la Sabiduría, que el conocimiento de Dios es mediatizado por la inteligibilidad del mundo y por las estructuras cognoscitivas humanas ${ }^{11}$.

Ha sido una posición recurrente y enfática del Papa Emérito, Benedicto XVI, aun desde antes que fuera prefecto de la Sagrada Congregación para la Doctrina de la Fe, subrayar el papel que desempeña la razón en el seno de la religión cristiana ${ }^{12}$. En los últimos años han brotado pretensiones de reivindicar exclusivamente la raíz judaica del cristianismo.

10 Romanos 1, 18-23

11 El libro de la Sabiduría, escrito originalmente en lengua griega, pertenece a la tradición de la Biblia griega o De los Setentas (traducida y conjuntada en Alejandría, siglos II-I a. C.), muestra el esfuerzo de su autor por integrar la espiritualidad hebrea con la mentalidad helénica.

12 Cfr. J. Ratzinger, "Theologia perennis? Über Zeitgemä eit und Zeitlosigkeit in der Theologie", Wort und Wahrheit, N 15, 1960, 180; J. Ratzinger, El Dios de la fe y el Dios de los filósofos, Taurus, Madrid 1962, 43 [lección dictada en 1960]; J. Ratzinger, Introducción al Cristianismo, Sígueme, Salamanca 2001 [ed. orig. 1968] 11; J. Ratzinger, Natura e compito della teologia, Jaca Book, Milán 1992; J. Ratzinger, “¿La verdad del cristianismo?” (Lectura impartida en la Sorbona de París el 27 de noviembre de 1999. Traducción del francés: Lucía Segovia). Istor, México, año 1 núm. 2, 2000, 11-25; J. RATZINGer, Fe, verdad, tolerancia. El cristianismo y las religiones del mundo, Sígueme, Salamanca 2005 [ed. orig. (2003) Fede, verità, tolleranza. II cristianesimo e le religioni del mondo, Cantagalli, Siena]. Benedicto XVI, "Fe, Razón y Universidad. Recuerdos y reflexiones” en Benedicto XVI, G. Bueno, J. Prades, Faroug, Juaristi, Nusseibe, Spaemann, Weiler, Dios salve 
Pero desde la Reforma y el impacto que tuvo esta en la filosofía moderna hemos observado esfuerzos por depurar al cristianismo de todo elemento helénico ${ }^{13}$. También ha sido palpable que en los años posteriores a la Reforma se ha tratado de romper el vínculo entre la herencia helénica (la filosofía que se concretiza en la modernidad ilustrada) y la fe cristiana, que va a ser descalificada como "superstición irracional" que ensombrece la inteligencia ${ }^{14}$. Joseph Ratzinger ha sostenido que el cristianismo no puede entenderse de manera cabal prescindiendo de sus raíces helénicas, particularmente de la filosofía griega y del tipo de racionalidad allí desarrollada. Además, desde luego, de las propiamente evangélicas y del monoteísmo bíblico ${ }^{15}$.

Ciertamente, desde los tiempos del paleocristianismo se gestó una larga tradición desmitificadora y apologética, optando por una concepción racional de Dios frente a las concepciones "primitivas" o mitológicas, articulando así un binomio difícil de disolver: fe-razón ${ }^{16}$. El cris-

a la razón, Encuentro, Salamanca 2008, 29-42 [Alocución en la Universidad de Ratisbona, septiembre 12, 2006].

13 J. B. Metz, "Anamnetische Vernunft", en A. Honneth, (1989), Zwischenbetrachtungen, Frankfurt a. M.: J. B. Metz, Anamnetische Vernunft. Untersuchungen zu einem Begriff der neuen Politischen Theologie, Münster 2001: LitVerlag. Cfr. O. Ruz, M., G. Rosolino, C. Schickendantz, "Razón anamnética, sufrimiento ajeno y teodicea. Claves de lectura, logros y límites de la obra de Johann Baptist Metz", Teología y Vida, XLIX, 2008, 575-603.

14 En la alocución en la Universidad de Ratisbona, el entonces Papa señalaba la inspiración reformista de esta tendencia a la deshelenización del cristianismo y el impacto de la Reforma en el pensamiento moderno desde comienzos del siglo XVI hasta el siglo XVIII. Benedicto XVI, "Fe, Razón y Universidad”..., 40.

15 J. Ratzinger, “¿La verdad del cristianismo?”..., 11-25. A propósito de las relaciones entre filosofía griega y pensamiento judío, puede analizarse una interpretación paralela en J. Habermas, pero en sentido contrario, decantada hacia el monumental proyecto filosófico de este autor. Habermas señala: "Sin esta infiltración del pensamiento genuinamente judío y cristiano en la metafísica griega no hubiéramos podido configurar aquel entramado de conceptos específicamente modernos que convergen en un concepto de razón a la vez comunicativa [la que heredamos de la Ilustración y de la teoría crítica de la sociedad] e históricamente situada [la que heredamos del historicismo y de la crítica hermenéutica hacia el positivismo]": J. Habermas, "Israel o Atenas: ¿A quién pertenece la razón anamnética? Johann Baptist Metz y la unidad en la pluralidad multicultural”, en Fragmentos filosóficoteológicos, Trotta, Madrid 1999, 89-100 [ed. orig. 1997].

16 J. Ratzinger, “¿La verdad del cristianismo?”..., 11-25. 
tianismo se entendió a sí mismo desde muy pronto como una religión ilustrada, para no ser considerada como un mito más, capaz de convivir con muchos otros en el marco del politeísmo pagano. Se concibió a sí mismo como la verdad que salva; verdad revelada, accesible y justificada doblemente, tanto en el terreno de la razón natural como en el de la fe sobrenatural. Esto es lo podemos entender cuando, desde el areópago de Atenas San Pablo presenta el cristianismo con la pretensión de ser la religio vera ${ }^{17}$. Lo cual significa que la fe cristiana allí anunciada no se basaba en la poesía ni en la política, esas dos grandes fuentes de la religión griega y romana; sino que se basaba en el conocimiento racionalnatural, tal y como lo manifiesta el fragmento arriba citado de la Carta a los Romanos.

Los Padres Alejandrinos del siglo III, Clemente y Orígenes, sostuvieron la idea de promover una gnosis cristiana bajo el supuesto de que la filosofía para los griegos era el equivalente a la ley para los judíos, y ambas -ley y filosofía - eran la antesala a la revelación de la verdadera sabiduría: el mensaje de Cristo. Nos dice Clemente en su obra Los tapices (Stromata): "Antes de la venida del Señor, la filosofía era necesaria a los griegos para la justicia. Ahora resulta útil para conducir a los hombre al culto a Dios". Se lee en otro pasaje de la literatura sapiencial del Antiguo Testamento:

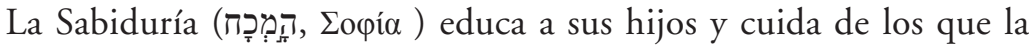
buscan. El que la ama ama la vida; los que parten de mañana en su búsqueda serán colmados de alegría. El que la posee alcanzará al fin la gloria; el Señor le dará su bendición. Los que la sirven se hacen los ministros del Santo, los que la aman son amados del Señor. El que la escucha tendrá un juicio acertado, el que le obedece estará seguro ${ }^{18}$.

Además, la filosofía (entendida como Sabiduría) era ya una propedéutica de salvación. Es por ello que Clemente considera que la filosofía griega - proveniente de la racionalidad humana (logos) y en coherencia con la Sabiduría divina (Logos)-, "hace un trabajo preliminar, preparatorio, disponiendo el camino a aquel a quien Cristo hace después perfecto" 19 .

17 Hechos 17, 16-34.

18 Eclesiástico (Sirácida) 4, 11 ss.

19 Clemente de Alejandría, Stromata I, 5, citado en C. Fernández, Los filósofos medievales. Selección de textos No I, BAC, Madrid 1979, 59. Cfr., H. ZaGAL, "Fe 
Como puede inferirse, las fuentes de la articulación fe-razón en el cristianismo primitivo las encontramos en la apología cristiana, que a su vez se alimenta de las apologías judaicas y de la crítica filosófica a los mitos y al politeísmo de su tiempo, tales fuentes tenían en común la crítica al lenguaje unívoco, a las imágenes que cada pueblo se hacía de las deidades. Esto lo encontramos en Heráclito, en Jenófanes, en los cínicos, estoicos, epicúreos y escépticos. Grecia tuvo su propia Ilustración, y el resultado de la superación de una religiosidad mitológica fue la idea de la existencia de un cosmos inteligible y la correspondiente noción abstracta de un dios racional. Dicha noción se concretiza en el pensamiento judeocristiano, puesto que en esa tradición religiosa, el conocimiento de la inteligibilidad del mundo permitirá conocer de modo mediato la inteligibilidad de su autor ${ }^{20}$. Los primeros cristianos se enfrentan en la defensa del mensaje de Cristo al paganismo, principalmente, de la cultura grecorromana; también el judaísmo en estos primeros tiempos es rival del cristianismo. A partir del año 100 de nuestra era, el problema entre cristianismo y filosofía se pone delicado. El cristianismo invade las clases cultas. Los cristianos defienden su fe frente al poder civil, lo que los lleva directo al martirio, tal como lo atestigua el bello texto, atribuido a Quadrato (h. 125-126), Discurso a Diogneto ${ }^{21}$. El cristiano culto ya gana cierto prestigio político. Empieza a defender las convicciones con argumentos apoyados en el diálogo e intercambio; los cristianos formados intelectualmente se orientan por este sendero. Tratan de refutar las acusaciones y calumnias que les hace el paganismo. Frente a las herejías tienen que defender las bases de su credo y se apoyan de las estructuras conceptuales de la misma filosofía pagana.

Como afirma el cardenal Ratzinger, en el cristianismo, la racionalidad se volvió religión y no su adversario. Ambas dimensiones de la religión, la naturaleza en su reino eterno y la necesidad de salvación del hombre en sufrimiento y en lucha, que estaban siempre separadas, quedan ahora vinculadas. La racionalidad puede volverse una religión, porque el Dios

en la razón. La herencia de Clemente alejandrino en la filosofía", en Efemérides mexicana, vol. $30, \mathrm{n}^{\circ} 88$, enero-abril 2012, 15-26.

20 Sabiduría $13,1-9$

21 D. Ruiz Bueno, Discurso a Diogneto en Padres apostólicos y apologistas griegos (s. II), BAC, Madrid 2002, 653-663. 
de la racionalidad entró a su vez en la religión. Esto es lo que constituye la apología del cristianismo como religio vera:

El elemento que reivindica finalmente la fe, la palabra histórica de Dios ¿no es acaso el presupuesto para que la religión pueda volverse ahora hacia el Dios filosófico, que no es un Dios meramente filosófico y que sin embargo no desdeña el conocimiento filosófico sino que lo asume? ${ }^{22}$.

En consecuencia, porque el cristianismo se entendió como la victoria de la desmitologización, la victoria del conocimiento y con ella la de la verdad, debía por fuerza considerarse universal y llevarse a todos los pueblos: no como una religión específica que reprime a otras, no como un imperialismo religioso, sino más bien como la verdad que vuelve superflua la apariencia. Y es por ello justamente que en la amplia tolerancia de los politeísmos paganos, este movimiento religioso e ideológico apareció necesariamente como intolerable, y hasta como enemigo de la religión popular o imperial, acusando a los seguidores de "ateísmo" o impiedad $(\dot{\alpha} \sigma \varepsilon ́ \beta \varepsilon 1 \alpha)^{23}$. Apunta Ratzinger en otra obra lo siguiente:

La fe cristiana optó [...] por el Dios de los filósofos frente a los dioses de las religiones: esto es, por la verdad del ser mismo frente al mito de la costumbre. Esta fue la razón por la que se tachó de ateos a los miembros de la iglesia primitiva. La Iglesia rechazó todo el mundo de la antigua religio, no aceptó nada de ella: la consideraba una pura y simple costumbre vacía que se alzaba contra la verdad. Para los antiguos, el Dios de los filósofos -que ya no tenía sitio algunono era religiosamente significativo. Por eso, mantenerlo, confesarlo como único y como todo, se veía como una negación de la religión - de la religio-, como ateísmo. Justamente en la sospecha de ateísmo que tuvo que afrontar el cristianismo primitivo es donde se ve con claridad su orientación espiritual, su oposición frente a la religio y la costumbre sin verdad: su opción exclusiva por la verdad del $\operatorname{ser}^{24}$.

El paleocristianismo no se limitó a la relatividad y a la convertibilidad de las imágenes, de suerte que incomodó en especial la utilidad política de las religiones y puso en peligro los fundamentos del imperio romano

22 J. Ratzinger, “¿La verdad del cristianismo?”..., 18.

23 J. Ratzinger, “¿La verdad del cristianismo?”..., 16. (recuérdese el Discurso a Diogneto).

24 J. Ratzinger, Introducción al Cristianismo..., 121. 
que se asentaba en la creencia en la divinidad del emperador ${ }^{25}$. No quiso ser una religión entre otras, sino la victoria de la inteligencia sobre el mundo de las religiones. Desde la época del cristianismo primitivo la racionalidad se emparentó con esta fe al tener un objetivo común: la verdad.

Siguiendo a San Agustín, Ratzinger afirma que el cristianismo y su preparación interior encuentran sus precursores en la racionalidad filosófica y no en las religiones. El cristianismo, de acuerdo con la tradición bíblica normativa, no se funda en imágenes y presentimientos míticos, al contrario, tiende hacia la esfera divina, la cual es capaz de advertir el pensamiento racional aun cuando esté volcado hacia la realidad temporal, tal y como lo muestran las citas con las que iniciamos este apartado.

En esa misma línea, el ejemplo de Justino Mártir es paradigmático. Puede verse como una figura sintomática de esta concepción racional de la fe cristiana: san Justino estudió todas las filosofías y al final reconoció en el cristianismo la vera philosophia. Al convertirse al cristianismo, no renegó, según su propia convicción, de la filosofía, sino que apenas entonces se hizo en verdad filósofo. Justino, filósofo y cristiano, sirve de ejemplo de cómo la victoria del cristianismo respecto a las religiones paganas fue posible gracias a su pretensión de inteligibilidad, y respecto a las filosofías vigentes debido a su dimensión integral y antropocéntrica de la salvación. Nos dice san Justino en su célebre diálogo con el hebreo Trifón ( $\mathrm{n}^{\circ}$ 2), que la filosofía [léase: la razón humana y Sabiduría] "es una” y ella nos conduce a Dios: "[...] La filosofía, efectivamente, es en realidad el mayor de los bienes, y el más precioso ante Dios, al cual ella es la sola que nos conduce y recomienda. Y santos, a la verdad, son aquellos que a la filosofía consagran su inteligencia"26.

El maridaje entre cristianismo y racionalidad, desde los orígenes de este movimiento religioso, se centra en la necesidad de responder a ese natural -y racionalmente legítimo- cuestionamiento sobre si la razón o lo racional se hallan o no en el comienzo de todas las cosas y en su fundamento. Se trata de esclarecer si lo real surgió de la base del azar y de la necesidad, y por consecuencia, de lo que no tiene razón. Es el mismo

25 También desde sus orígenes mismos cuestionó el clericalismo judío, la obsesión cuasi patológica e inhumana de legalismo hebreo.

26 Justino Mártir, Diálogo con Trifón en Ruiz Bueno, D. Padres apostólicos y apologistas griegos (s. II), BAC, Madrid 2002, 1108. 
problema moderno y contemporáneo de determinar, de una vez por todas, si la razón es un producto periférico y accidental de lo irracional y si es finalmente tan insignificante en el océano de lo irracional, o si sigue siendo verdad lo que constituye la convicción fundamental de la fe cristiana y de la filosofía que le subyace ${ }^{27}$.

La respuesta es fácil de identificar: las palabras con las que comienza el evangelio según san Juan: "En el principio era el Verbo"28 indican que en el principio no solo existía la palabra o la razón, sino el orden. En el principio no existía el caos o el azar, sino la inteligibilidad. Tal inteligibilidad es la referencia del cristiano, al que se dirige el texto joánico, para orientar su relación con el mundo, con los demás y, por supuesto, con Dios mismo y así encontrar un fundamento absoluto que le dé estructura y coherencia a la realidad que le circunda y a su propia existencia.

Porque está claro: si la fe capta el concepto filosófico de Dios y dice: "lo Absoluto - del que vosotros sabíais de alguna manera- es el Absoluto del que habla Jesucristo (que es la 'Palabra') y al que se le puede hablar”, sin embargo, no por esto se suprime sin más la diferencia entre fe y filosofía, ni mucho menos se transforma en fe lo que hasta ahora era filosofía. La filosofía sigue siendo más bien otra cosa con su propia entidad, a la que se refiere la fe para expresarse en ella como esa otra cosa y poder así hacerse comprensible ${ }^{29}$.

Desde los primeros escritos se observa cómo el cristianismo entró en escena como síntesis de fe y razón, como "religión ilustrada" que hace creíble su pretensión de ser la verdadera religión recurriendo al discurso racional y al Logos mismo, que es la fuerza creadora de todo ser. Ratzinger ha insistido siempre en que esta síntesis de razón y fe es consustancial al cristianismo, que no quiere degradarse en fideísmo. La racionalidad de la fe cristiana comporta consigo varios elementos positivos que resumimos en dos, a saber: la purificación de la imagen de Dios respecto de las falsas representaciones, y la concepción de un Dios que se puede reconocer por el pensamiento racional. Quizá de aquí pueda derivarse la objeción de por qué se trata de identificar al Dios revelado (providente, amoroso, misericordioso) con el dios de los filósofos (abstracto, conceptual e impersonal). Más que responder la objeción, de hecho tenemos

\footnotetext{
27 J. Ratzinger, “¿La verdad del cristianismo?”..., 23.

28 'Ev $\dot{\rho} \rho \chi \tilde{n} \tilde{\eta} v$ ó $\lambda o ́ \gamma o s$.

29 J. Ratzinger, El Dios de la fe y el Dios de los filósofos..., 40.
} 
que argumentar que esta es la síntesis de la concepción de Dios que se halla presente en el teísmo cristiano: Dios está en la naturaleza (natura Deus) pero la naturaleza no es Dios (non tamen omnis natura est Deus). Dios es inmanente, puesto que está presente en la naturaleza como su creador, y trascendente, porque no se identifica con ella, más que como relación adecuada y proporcional de causa-efecto. Dios es la causa de la naturaleza, pero la naturaleza como tal no es Dios. Como afirma Ratzinger, esto permite la separación necesaria entre metafísica y física ${ }^{30}$. El Dios revelado, el Dios verdadero, también es un Dios racional, accesible por el pensamiento racional. Se revela como principio inteligible, como causa eficiente, final y ejemplar de la naturaleza ${ }^{31}$. Pero solo el Dios verdadero, aquel que podemos reconocer por el pensamiento en la naturaleza, es objeto de plegarias:

Diferencia y armonía entre ambas [entre fe y filosofía]. Por tanto, el Dios de Abraham, Isaac y Jacob será un Dios con el que podemos hablar, a la vez que acceder a Él -tal vez de un modo más lejano pero real- por medio de la razón. No hay pues un abismo, sino un puente (quizá bastante largo y algo arriesgado de cruzar, pero puente al fin y al cabo). El Logos divino quiere contar con el logos humano ${ }^{32}$.

¿Por qué razón? El Dios verdadero, el Dios racional que se revela en su obra, se volcó hacia las criaturas, especialmente hacia la criatura humana. Este Dios que se reconoce por la razón, invirtió el movimiento natural de la tendencia antropológica y religiosa por excelencia -el ser humano naturalmente se religa hacia lo superior y trascendente-. Pero en el cristianismo, el Dios verdadero se religa con su criatura, se vuelve hacia abajo, de tal modo que lo trascendente se dirige hacia lo inmanente para reivindicar su condición, para salvarlo del sufrimiento. El hombre puede vincularse con Dios porque Dios se vinculó al hombre. Aquí es donde la moral cristiana cobra su sentido y se fundamenta su praxis, en la solidaridad del Dios verdadero, del Dios racional, con la naturaleza humana finita, frágil y contingente. A decir de Ratzinger, la victoria del cristianismo sobre las religiones paganas fue posible, por un lado, gracias a su pretensión de inteligibilidad, y por el otro, a la seriedad

\footnotetext{
30 J. Ratzinger, “¿La verdad del cristianismo?”..., 17-18.

31 Colosenses 1, 15-17.

32 P. Blanco, "La razón en el cristianismo. Una reivindicación de Joseph Ratzinger" en Scripta Theologica, XXXVII, 2005/2, 646.
} 
moral del cristianismo ${ }^{33}$, característica que el mismo san Pablo había también relacionado con la racionalidad de la fe cristiana. Las exigencias esenciales, iluminadas por la fe cristiana, del Dios único en la vida del hombre, satisfacen las exigencias del corazón humano, de cada hombre, de suerte que cuando se le presentan estas exigencias, el ser humano, mediante su racionalidad, las reconoce como derivadas del Bien ${ }^{34}$. Logos y agápe (caritas), verdad y amor son los elementos que se vinculan para operar una auténtica transformación del concepto frío e impersonal de Dios que tenían los filósofos: se acepta, pero se cambia y enriquece. A este respecto señala Ratzinger:

[...] La fe cristiana optó solamente por el Dios de los filósofos y, por eso, este es el Dios al que se le puede rezar y el Dios que habla al hombre. La fe cristiana dio a este Dios un significado nuevo, lo sacó del terreno puramente académico y lo transformó profundamente. [...] Este Dios que se concebía como puro ser o puro pensar, eternamente recluido en sí mismo, sin proyección alguna hacia los hombres y su pequeño mundo; este Dios de los filósofos [...] es ahora -para la fe- el hombre-Dios, que no es solo pensar del pensar (eterna matemática del universo), sino también agápe, fuerza de amor creador. En este sentido, en la fe cristiana se repite la misma experiencia que tuvo Pascal una noche en que escribió estas palabras en un trozo de papel, que luego cosió al forro de la casaca: "Fuego. Dios de Abraham, de Isaac y de Jacob. No el Dios de los filósofos y sabios" ${ }^{35}$.

Como conclusión provisional para este segundo apartado, podemos afirmar que la fe cristiana se ha presentado desde sus orígenes como la opción para la prioridad de la razón y de lo racional.

\section{LA NECESIDAD MUTUA ENTRE RAZÓN Y FE CRISTIANA EN LA ÉPOCA POST- MODERNA Y POST-SECULAR}

La situación del hombre contemporáneo en cuanto al conocimiento de la verdad puede describirse con claridad a partir de un cuento popular de la India, cuya versión moderna la encontramos en el poeta John Godfrey Saxe (1816-1887): El poema de los hombres ciegos y el elefante, aunque este autor lo aplica a los conflictos religiosos. Escribió Saxe en 1873:

\footnotetext{
33 J. Ratzinger, “¿La verdad del cristianismo?”..., 18-19.

34 Romanos 2, 14

35 J. Ratzinger, Introducción al Cristianismo..., 122.
} 
Seis eran los hombres de Indostán / tan dispuestos a aprender, que al Elefante fueron a ver (aunque todos eran ciegos), pensando que mediante la observación / su mente podrían satisfacer.

El primero se acercó al elefante / y cayéndose sobre su ancho y robusto costado, en seguida comenzó a gritar: “¡Santo Dios! ¡El elefante / es muy parecido a una pared!”

El segundo, palpando el colmillo, exclamó: “¡Oh! ¿Qué es esto / tan redondo, liso y afilado? Para mí está muy claro, ¡esta maravilla de elefante / es muy parecido a una lanza!"

El tercero se acercó al animal, y tomando entre sus manos / la retorcida trompa, valientemente exclamó: "Ya veo", dijo él, “¡el elefante es muy parecido a una serpiente!"

El cuarto extendió ansiosamente la mano / y lo palpó alrededor de la rodilla: "Evidentemente, a lo que más se parece esta bestia / está muy claro", dijo él, / "es lo suficientemente claro que el elefante ¡es muy parecido a un árbol!”

El quinto, quien por casualidad tocó la oreja, / dijo: "Incluso el hombre más ciego / es capaz de decir a lo que más se parece esto; / niegue la realidad el que pueda, / Esta maravilla de elefante / ¡es muy parecido a un abanico!"

El sexto tan pronto comenzó a tantear al animal, / agarró la oscilante cola / que frente a él se encontraba, / "Ya veo,” dijo él, “¡el elefante / es muy parecido a una cuerda!"

Y así estos hombres de Indostán / discutieron largo y tendido, cada uno aferrado a su propia opinión / por demás firme e inflexible, / aunque cada uno en parte tenía razón, / ¡y al mismo tiempo todos estaban equivocados!

MORALEJA: Así también, a menudo en las guerras teológicas / los contendientes, pienso yo, / discuten en la total ignorancia / de lo que el otro quiere decir; / y parlotean acerca de un elefante ¡que ninguno de ellos ha visto! ${ }^{36}$

36 "It was six men of Indostan / To learning much inclined, Who went to see the Elephant. (Though all of them were blind), That each by observation / Might satisfy his mind. The First approached the Elephant, And happening to fall / Against his broad and sturdy side, At once began to bawl: God bless me! but the Elephant / Is very like a wall! The Second, feeling of the tusk, Cried, Ho! what have we here / So very round and smooth and sharp? To me tis mighty clear / This wonder of an Elephant / Is very like a spear! The Third approached the animal, 
Esta sencilla pero elocuente historia nos muestra la situación de escepticismo que señalábamos al principio, y desde nuestro punto de vista pone de manifiesto la necesidad de criterios racionales para discernir la validez de la multiplicidad de puntos de vista en este contexto plural.

La validez de la razón y su relación con la religión se encuentran sometidas a escrutinio desde hace varias décadas en las que comenzó a afirmarse el fin de la metafísica, la crisis de la razón. En el debate con Jürgen Habermas sostenido en Munich en 2004, el entonces cardenal Ratzinger formulaba de manera breve el ideal ilustrado acerca de la religión, tal y como lo concibe su interlocutor, cuando se pregunta lo siguiente: “ ¿es verdad que la gradual eliminación de la religión, su superación, se ha de considerar como progreso necesario de la humanidad, capaz de permitirle hallar el camino de la libertad y de la tolerancia universal?" ${ }^{37}$. Ratzinger admite la existencia de "patologías religiosas" que sustentan el terrorismo fundamentalista, y por eso el diálogo con la razón (consustancial al cristianismo) ejerce un saludable efecto sobre la fe religiosa.

And happening to take / The squirming trunk within his hands, Thus boldly up and spake: I see, quoth he, the Elephant / Is very like a snake! The Fourth reached out an eager hand, And felt about the knee. What most this wondrous beast is like / Is mighty plain, quoth he; / This clear enough the Elephant / Is very like a tree! The Fifth, who chanced to touch the ear, Said: Even the blindest man / Can tell what this resembles most / Deny the fact who can / This marvel of an Elephant / Is very like a fan!? The Sixth no sooner had begun / About the beast to grope / Than, seizing on the swinging tail / That fell within his scope / I see, quoth he, the Elephant / Is very like a rope! And so these men of Indostan / Disputed loud and long, Each in his own opinion / Exceeding stiff and strong, Though each was partly in the right / And all were in the wrong! MORAL: So oft in theologic wars, / The disputants, I ween, / Rail on in utter ignorance / Of what each other mean, / And prate about an Elephant / Not one of them has seen!. [J. G. SAXE, "The Blind Men and the Elephant; John Godfrey Saxe's version of the famous Indian legend. Pictures by Paul Galdone", Whittlesey House, New York 1963, (ed. orig. 1873)]. En la conferencia de 1998, Joseph Ratzinger nos remite a su propia versión de esta historia (Véase: J. Ratzinger, “¿La verdad del cristianismo?”..., 11).

37 J. Ratzinger, "Lo que cohesiona al mundo. Los fundamentos morales y prepolíticos del Estado liberal”, en J. Habermas-J. Ratzinger, Entre razón y religión. Dialéctica de la secularización, FCE, México 2008, 43 [ed. orig. (2005) Editrice Vaticana, Roma; (2005) Herder Verlag, Freiburg i. B.]. Véase al respecto del encuentro en la Academia Católica de Baviera: M. Urrea C. "Las etapas del diálogo Habermas / Ratzinger y sus implicaciones para la filosofía de la religión", en Efemérides mexicana, vol. 31, $\mathrm{n}^{\circ}$ 91, 2013, 151-180. 
Pero el actual Papa Emérito no deja de indicar una patología menos evidente para el mundo actual: la "patología de la razón":

Antes había surgido la cuestión de si hay que considerar la religión como una fuerza moral positiva; ahora debe surgir la duda sobre la fiabilidad de la razón. Al fin y al cabo, la bomba atómica es un producto de la razón; al fin y al cabo, también la producción y selección de hombres han sido creadas por la razón. En ese caso, ¿no habría que poner a la razón bajo observación? ${ }^{38}$.

Así pues, religión -en este caso, fe cristiana- y razón deberían señalarse mutuamente sus propios límites y ayudarse a encontrar el camino acertado. La razón debería ilustrarse a sí misma, reconociendo la ayuda que le puede ofrecer una religión ilustrada. Las posibilidades de la racionalidad se amplían en la medida en que la religión desestima a la razón humana de sus solas pretensiones absolutizadoras. Le evita recaer en la soberbia moderna que desenmascaró S. Freud cuando detallaba las tres grandes ofensas que sufrió el amor propio de la humanidad ${ }^{39}$. Las posibilidades de la racionalidad humana se expanden no por fuerza propia, sino en la medida en que se abren a la dimensión metafísica y trascendente, que no es irracional, ni mágica ni mítica.

El futuro de la fe cristiana y su capacidad para seguir proponiéndose como creíble, depende esencialmente de que sea fiel a esa vocación suya de proponerse como verdad a la que cabe aproximarse también por el camino de la razón ${ }^{40}$. Pertenece a la esencia del cristianismo el reivindicar la dignidad de la razón humana, el presentarse como religión ilustrada. Evidentemente, no podrá hacer valer este título más que si no rehúye el encuentro con la filosofía, la ciencia y la cultura. El cristianismo ha de exponerse a la crítica racional, ha de descender a la arena de la discusión. Pero, de acuerdo con la exposición precedente, no ha de verse en ello algo así como un destino histórico adverso, un precio elevado que uno no tiene más remedio que pagar para acceder a la respetabilidad social en un mundo pluralista. El encuentro con la razón, también con la razón increyente, con las razones de quienes dudan del potencial de la razón,

38 J. RATZinger, "Lo que cohesiona al mundo. Los fundamentos morales y prepolíticos del Estado liberal”..., 43-44.

39 S. Freud, Introducción al narcisismo (1914); Una dificultad del psicoanálisis (1917).

40 J. M. Mardones, ¿Adónde va la religión?: cristianismo y religiosidad en nuestro tiempo, Sal Terrae, Santander 1996. 
es en realidad una exigencia interna del propio cristianismo en tiempos post-modernos y post-seculares ${ }^{41}$.

Parafraseando a los fundadores de la Teoría crítica de la sociedad, si el cristianismo es desde su origen una religión ilustrada, entonces no podrá renunciar a la razón, deberá ilustrarse a sí mismo, para evitar caer no solo en mitología sino en ideología, en cuanto conjunto de "verdades" que impiden la autorrealización de los individuos y la "emancipación" del género humano.

La paradoja de presentar al cristianismo como una religión ilustrada consiste, a nuestro modo de ver, en que esta crítica sobre sí mismo puede conducir a una crítica total y autorreferencial, al punto de autosuprimirse y que la razón termine no solo ahogando la fe y el "misterio", sino ahogándose a sí mismo en un paralizante escepticismo. Pero, del mismo modo, si la fe cristiana renuncia a esa racionalidad inherente que hemos mencionado, también es latente el riesgo de aniquilarse a sí misma -como religión ilustrada- y recaer en la irracionalidad, el fanatismo y fideísmo que tradicionalmente ha combatido en aras de esa misma verdad y que recientemente se han manifestado como amenazas latentes para esa misma emancipación deseada. He ahí la dialéctica del cristianismo y la paradoja de su racionalidad irrenunciable. ¿Puede la racionalidad del cristianismo, sin renegar de sí, renunciar a la prioridad de lo racional sobre lo irracional, a la existencia original del logos y a sus exigencias inherentes? ${ }^{32}$.

\section{Acotaciones finales}

La fe cristiana tiene que hacer honor a la razón humana, con la que se ha comprometido en el momento mismo de su sistematización y tiene que dar razón de su esperanza. Hoy, ante la vuelta de fundamentalismos e irracionalismos pseudo-científicos, de objetivismos que monopolizan la verdad y de subjetivismos ingenuos e intransigentes, este reto es especialmente urgente ${ }^{43}$. Occidente, desde hace mucho, está amenazado

41 M. Borghesi, Secularización y nihilismo..., 38; J. M. Mardones, Posmodernidady cristianismo. El desafío del fragmento, Sal Terrae, Santander 1988; J. M. Mardones, Sintomas de un retorno. La religión en el pensamiento actual, Sal Terrae, Santander 1999.

42 J. Ratzinger, “¿La verdad del cristianismo?”..., 24.

43 Cfr., J. Moltmann, El Dios crucificado, Sígueme, Salamanca 1975. 
por esta aversión contra los interrogantes fundamentales de su razón, y así solo puede sufrir una gran pérdida. Nos recuerda Benedicto XVI que la valentía para abrirse a la amplitud de la razón, y no la negación de su grandeza, debe ser el programa con el que una religión que se precie de ser la verdad revelada, entre en el debate de nuestro tiempo. "No actuar según la razón, no actuar con el logos, es contrario a la naturaleza de Dios" ${ }^{44}$.

Para concluir me permito hacer una última reflexión. Lo que hemos expuesto anteriormente no justifica que el cristianismo termine despreciando el misterio o negando la "experiencia" de la fe vivida. Ante el Logos (como Verbum, Palabra) no solo hay que racionalizar, sino "escuchar" Esto significa que en la fe cristiana se requiere la puesta en práctica de la metodología hermenéutica planteada por Paul Ricoeur, a saber: purificar al discurso de sus excrecencias, liquidar los ídolos, ir de la ebriedad a la sobriedad, hacer de una vez el balance de nuestra pobreza; primero tener una actitud de sospecha ante lo que tradicionalmente se nos ha mostrado como verdad, como normalidad, y después una actitud de escucha, una «segunda ingenuidad» como Ricoeur la llama; es decir, una fe pasada por la crítica y que, sin embargo, se vive después con la entrega y la espontaneidad del creyente ingenuo ${ }^{46}$. Voluntad de sospecha y voluntad de escucha; voto de rigor y voto de obediencia. Recuperemos en estos tiempos la lección hermenéutica de san Agustín en su Comentario al Evangelio de Juan: "¿Quieres entender? Cree, pues Dios dijo mediante un profeta: "Si no creéis, no entenderéis». Si no has entendido, cree. La inteligencia es, pues, premio de la fe. No te afanes por llegar a la inteligencia para

44 Cfr., Benedicto XVI, “Fe, Razón y Universidad”..., 42.

45 " "La fe viene de la escucha” (Romanos 10, 17), es esta una afirmación estructural permanente [...] que establece la diferencia fundamental con la simple filosofía, hasta el punto de que -en su espacio interior- puede desafiar la búsqueda filosófica de la verdad. Se podría decir: de hecho la fe viene del «escuchar», no del «reflexionar» -como la filosofía- y su ser consiste en el re-pensar (nach-denken) lo que se ha escuchado. Lo cual significa que en esta la palabra precede al pensamiento; en la filosofía, el pensamiento precede a la palabra": J. RATZINGER, Natura e compito della teologia..., 137; Cfr., J. Ratzinger, Introducción al cristianismo..., 80-81.

46 Cfr., P. Ricoeur, Freud. Una interpretación de la cultura, Siglo XXI, México 2002, 32-35. 
creer, sino cree para llegar a la inteligencia, ya que, si no creéis, no entenderéis $($ Is 7,9$){ }^{\prime \prime}{ }^{4}$.

No solo la fe cristiana necesita de la racionalidad, sino que la misma racionalidad necesita de la fe para sobrevivir. Entre la fe cristiana y la racionalidad se da un necesario diálogo, que les llevará al recíproco apoyo y a la supervivencia en una época no siempre bien dispuesta a acogerlas.

Terminemos con las palabras de San Anselmo, que nos permiten enfatizar la necesidad de la razón aun para la fe, en la línea abierta por el santo de Hipona:

Señor, yo no pretendo penetrar en tu profundidad: ¿cómo iba a comparar mi inteligencia con tu misterio? Pero deseo comprender de algún modo esa verdad que creo y que mi corazón ama. No busco comprender para creer (esto es, no busco comprender de antemano, por la razón, lo que haya de creer después, sino que creo primero, para esforzarme luego en comprender. Porque creo una cosa: si no empiezo por creer, no comprenderé jamás ${ }^{48}$.

47 Tract. Ev. Io., 29.6, en Agustín de Hipona, Opera omnia: "Si quis crediderit; et hoc consilium dederam: Si non intellexisti, inquam: Crede. Intellectus enim merces est fidei. Ergo noli quaerere intelligere ut credas, sed crede ut intelligas: quoniam nisi credideritis, non intelligetis. (Nisi credideritis, non intelligeti: Is. 7, 9)”.

48 Proslogium 1 "Non tento, Domine, penetrare altitudinem tuam; quia nullatenus comparo illi intellectum meum, sed desidero aliquatenus intelligere veritatem tuam, quam credit et amat cor meum. Neque enim quaero intelligere, ut credam; sed credo, ut intelligam. Nam et hoc credo quia nisi credidero, non intelligam” . 
Resumen: El objetivo de este trabajo es reflexionar, a partir de algunos textos clave de Joseph Ratzinger, acerca de la relación que el cristianismo siempre ha tenido con la filosofía y con el tipo de racionalidad que se desarrolló en Occidente. El cristianismo nunca se ha asumido como una propuesta religiosa más, sino como "la verdad revelada". Desde sus orígenes ha tenido que convivir con múltiples ofertas religiosas y hoy en día no puede sustraerse a ello en un contexto marcado por el pluralismo, como el de nuestra época. Esta condición le impele actualmente a reivindicar su carácter racional inherente y afrontar los desafíos que cierto irracionalismo de la cultura posmoderna le pone frente a sí.

Palabras clave: Crisis de la razón; fe-razón; irracionalismo posmoderno; religión ilustrada.

Abstract: The purpose of this paper is to reflect, from a few key texts by Joseph Ratzinger, about the relationship that Christianity has always had to philosophy and the type of rationality that developed in the West. Christianity has never been assumed to be a more religious approach, but as "the revealed Truth". Since its inception has had to live with multiple religious offerings and today can not escape it in a context marked by pluralism, as in our time. This condition now impels it to vindicate its rational nature and face the challenges inherent to a certain irrationality of postmodern culture puts before it.

Keywords: Crisis of Reason, Faith-Reason, Postmodern Irrationalism, Illustrated Religion. 
